\title{
ANALYSIS OF SYMBOLS AUTHORITY THROUGH THE PERSPECTIVE OF ISLAMIC HOLISTIC STUDY
}

\author{
Unik Hanifah Salsabila $^{1^{*}}$, Aabidah Ummu Aziizah ${ }^{2}$ \\ ${ }^{1}$ Department of Islamic Education, Faculty of Islamic Studies, Universitas Ahmad Dahlan \\ Kapas Street No. 9, Yogyakarta, Indonesia. 55166 \\ *Email: unik.salsabila@pai.uad.ac.id \\ ${ }^{2}$ Department of Islamic Education Master, Faculty of Tarbiyah and Teacher Training, \\ Universitas Islam Indonesia \\ Demangan Baru Street No. 24, Yogyakarta, Indonesia. 55281 \\ Email: aabidah319@gmail.com
}

\begin{abstract}
The fundamental dialectical theory of the Berger model claims that humans are a product of society and society is a human product, so both require interaction and dialectics to influence each other in social life. Until the scope of the rite, each human is a judge to have a specific social function, if he has the influence to regulate, maintain and transmit sentiments from one generation to another. In other words, humans will always express their existence through artificial things and a sign for each human being to have connectivity with each other. Even if it reviewed historically, it is not necessarily born from the Islamic body ideologically. How much authorization of tangible symbols on religious practices in the Islamic paradigm? Are material symbols in spiritual practices limited to the manifestation of human creativity or sacred things that cannot contest? This scroll will continue until there is a discussion about it.
\end{abstract}

Keywords: authority, Islamic studies, philosophical, symbols

\begin{abstract}
Abstrak: Teori dialektika fundamental model Berger menyatakan bahwa manusia adalah produk masyarakat dan masyarakat adalah produk manusia, sehingga keduanya membutuhkan interaksi dan dialektika untuk saling mempengaruhi dalam kehidupan sosial. Hingga ruang lingkup ritus, setiap manusia adalah hakim yang memiliki fungsi sosial tertentu, jika ia memiliki pengaruh untuk mengatur, memelihara, dan meneruskan sentimen dari satu generasi ke generasi lainnya. Dengan kata lain, manusia akan selalu mengekspresikan eksistensinya melalui hal-hal yang artifisial dan merupakan pertanda bahwa setiap manusia saling berhubungan. Kalaupun ditinjau secara historis, belum tentu lahir dari tubuh Islam secara ideologis. Seberapa besar otorisasi simbol yang berwujud pada praktik keagamaan dalam paradigma Islam? Apakah simbol material dalam praktik spiritual terbatas pada manifestasi kreativitas manusia atau hal-hal sakral yang tidak dapat ditandingi? Pembahasan ini akan terus berlanjut.
\end{abstract}

Kata Kunci: filosofis, otoritas, simbol, studi Islam

\section{Introduction}

Humans will always express their existence through artificial things and a sign for each human being to have connectivity with each other. In addition to the expression on one's face as a medium to interpret feelings, beliefs and things that want to reveal so that their surroundings felt their existence, symbols also estimated as the most open and direct manifestations of human creativity. Even the extreme, is every word spoken by humans is a symbol that it has (Croft, 1990). "Every single one is a symbol. Every word is a symbol; every sentence structure those symbols". Religion becomes one aspect of human life that has a significant portion in the control of the use of symbols. Religious symbols become increasingly popular because their use is not limited by a person's socioeconomic differences, from the proletarian to the elite, all of whom have the right to wear them.

Zakiah Daradjat was quoted by Nata in his book Islamic Methodology Study saying that every individual human being will in essence, always be inclined to religion even though he did not carry out its provisions (Batubara, 2018). Moreover, when this life can be said to have entered the secular era, where freedom became a reference for the entire rotation of life, religion plays an essential role in humans (Keene, 2006). As noted by Bernard Cooke and Gary Macy, religious symbols and rituals become important tools that are inherent in each human individual and have strong interrelations (Cooke \& Macy, 2005). Predictions of scientists about the human relationship to the symbol are now proven and no longer 
just belong to the oligarchs or even be esoteric. Logos now do not need to be square off to be the focus of quite dramatic religious issues.

Late in 2014 and repeated back in the year 2019, the polemic symbol even not only unravels the scope of religion. Not only as an individual but also a colony of the holder policy and governance structure. As is the case in Quebec-Canada, the government proposed the making of the bill for all civil servants for not wearing all kinds of religious symbols because they are considered discriminatory and tend to provoke disputes (Mirzazadeh, 2014). Similar conditions also occur in Indonesia, where a polemic about mosque architecture is discussed by some Muslims as a symbol of religion outside of Islam and makes accusations between one another and Islamic sects.

\section{A. Symbols and Dialectics}

Etymologically, symbols in Kamus Besar Bahasa Indonesia (KBBI) interpreted as symbols. Symbols derived from the Greek cymbalo which means tossed together or put together in one idea or combine visible objects, so that the object represents a link (Simbol - Wikipedia Bahasa Indonesia, ensiklopedia bebas, 2020). The word symbol has similarities with symbols in English, which means sign, mark, object, representation of ideas, a system of, used to represent a particular group of ideas (Hornby et al., 1963). Arabic symbols known by many words depend on their scope. The symbols in the aqeedah transition are more often use words لمة ادل as for the use of words often applied to the scope of the law, then the word شدإِارة is more often used in the scope of anthropology in general, but another mention is in the holy book of the Qur'an which prefer to use بأبة pronunciation. The diversity of the mention of the symbol is none other than the referential it contains and the context that surrounds it. The terminological understanding of symbols shifts fundamentally, as suggested by David Jary and Julia Jary (a) a sign, in which the connection between the meaning and the flag is conventional rather than natural, (b) an indirect representation of an underlying meaning, syndrome, etc., for example, in religious symbolism and ritual (Pass et al., 2012). David J. and Julia J. believe that symbols that have a general nature, both derived from habits, habits and other agreements, the character will tend to be challenging to understand singly and can be used universally. However, Collin Cobuild still chose symbols as something that represented an idea or definition and was universal.

More systematically, through the publication of Peter L. Berger's social construction theory, formulates three elements that fundamentally form symbols in human life. Its namely externalization, objectivation and internalization (Berger \& Kellner, 1964). So, it can be interpreted that by consensus, each symbol that formed in human life ascertained to have three elements that can account. If drawn to the phenomenon of texts, inter-figures, predecessors, and all actions of the community will be in harmony, whereas if someone tries to interact with these symbols in the social environment will be accepted. If an internalization effort carried out, an identification process would automatically occur whether those who believe it or who do not believe it. Symbols carry the meaning of a symbol formed by humans and then associatively used in everyday life, and there are times when a symbol gives a universal sense and a single purpose and sometimes not. Tokens do not always carry complicated terms but also simple things. One absolute trait that is still taken by symbols is philosophical, and this is in line with the semiotic concept in interpreting symbols according to Charles Sanders Pierce, where logos are signs that have an inherent connection to an object or a picture that has a greater meaning (Kriyantono \& Sos, 2015).

Consciously, Peirce classifies three types of symbols based on the fundamental essence they contain (Peirce, 1960), that are: (a) indexical sign, which is a sign that represents an object or concept through a temporary, spatial or even causal relationship, for example, the presence of smoke signals that there was a fire before, there is a hole. The bullet indicates the bullet that fired; (b) Icons sign is a sign that reflects the structure of experience in several ways (Croft, 1990). Based on this context, the existence of icons defined as a semiotic system that refers to signs with physical shapes that are very similar to the characteristics of the situation, they are indicating (Crystal, 2008). Figures only apply to a single aspect of a concept and are never used to mark other attributes of the idea. It is possible to identify the object it represents without requiring additional information, for example, a time crossing symbol on a traffic light 
with two people's icon images. can directly be understood by the activity of passing people, although not always numbering two, it could be more or less; and (c) Symbol, which is a sign that does not have a clear link or similarity to the object it is describing. Extreme, that these kinds of linguistic symbols arbitrarily allocated and there is no inherent relationship between concepts and acoustic images (Saussure, 1959). For example, logos are visualized with angels to show the logo of holiness.

\section{B. Symbolic Interactionist Theory}

The symbolic interactionist approach is one of a kind of qualitative methodological approaches based on three main pillars. That are namely pragmatism, behaviorism and Darwin's theory of evolution. This theory views all human behavior, both interpersonal or community groups is a phenomenon of life that based on the way humans or active agents respond to the world around them. It's looking at the various possibilities and consequences of each symbol as if forcing the symbolic interactionist theory to be applied as a knife analysis of religious symbols which became the focal point in the discussion this time. Herbert Blumer became the cornerstone of the most formal and economic process, from which then emerged numerous concepts underlying symbolic interactionist theories, namely: (a) The sense that objects have for them is often human behaviors on an entity; (b) The meaning taken from the purpose is the product of human society's social contact; and (c) The sense that is born will always be open to him the way of evolution through the process of modification of interpretation by each human individual in its involvement with the signs it faces.

The premises of the symbolic interactionist theory above give birth to a set of practical principles in analyzing a symbolic phenomenon. First, based on this theory as a foothold of consciousness, humans will always be valued as thinking organisms born from social interaction. Second, the condition then creates a vehicle for learning for each individual to interpret and form symbols as a tangible manifestation of the emergence of the unique ability to "think" humans. Third, the existence of meanings and symbols will guarantee human entities to continue actions and interactions according to their characteristics. Fourth, the modification of meanings and symbols that occur amidst the dynamics of life is a rational response in interpreting the situation around him. Fifth, the ability of humans to interact is caused by their natural potential to interact with themselves. So that it allows humans to be able to examine each stage of their actions, assess the advantages and disadvantages of a movement in relative terms, and end works based on the objectives chosen. Sixth, the ultimate goal of this practical principle is the formation of a group or society (Veeger, 1985).

In this context, it has seen that symbolic interactionist theory views the phenomenon of symbols as something that arises due to the interaction between humans and their surroundings. The subjectivity tendency, which is the reason for the emergence is the element of profit, habits, or even changes that occur in humans or the environment itself. The sacredness of symbols through this theory is assessed with a different point of view, no longer sacred, which is absolute. Still, a symbolic entity is considered holy or profane by returning it to its original meaning and supporting instruments, because the valid symbol is the effort of social construction in daily life. So that later, when speaking from the perspective of religious symbols, this theory will test the birth of the epistemology of religious symbols which tend to be more relevant to the reality of life.

\section{Symbol of Equity}

Religious symbols are one type of logo that has the most success to be verified compared to other symbols. Through historical excavation, it mentioned that the fame of symbols only began in the 19th century through the emergence of religious symbols (Segal \& Saliba, 1978). The spiritual frame that sheltered them made the existence of religious symbols have special treatment both in theory and practice. As stated by Martin Lings in his journal entitled The Quranic Symbolism of Water follows (Lings, 1968): "A symbol is not a concrete image arbitrarily chosen by a man to illustrate some abstract idea; it is the manifestation, in some lower mode, of the higher reality which it symbolizes and which stands in as close a relationship to it as the root of the tree to leaf..." 
Martin explained that symbols are not concrete images that were chosen authority fully by humans to illustrate specific abstract ideas. He said that the logo is a manifestation that is analogous to the position found in the roots of the tree and leaves. In this context, not a simple condition if specific individuals are brave to associate symbols with religion. It is based on the demand for a broad spectrum of meanings so that they overlap synchronous and diachronic paths simultaneously. The meaning of religious symbols tends to use as the highest expression of human beings. When linking the reality of life with the transcendent dimension (Segal \& Saliba, 1978) or in other words, tokens often referred to as representations of autonomous revelation whose appearance is caused by the interference of the human construction that created them. As an example, the history of the use of the symbol of the cross for Christians. It mentioned in various narrations that initially the shape of the cross was a visualization of contempt for Christians (Segal \& Saliba, 1978). The display formed from the condition of the Jesus who was believed to be God and experienced the tragedy of mounting in crucified that makes he died. However, entering the year 326 M, Helena, wife of Emperor Constantine Chlorus and mother of Constantine the Great had a dream. Christians later believed Helena's dream as a cosmological sacred turning point.

Helena's dream tells about her spiritual journey to Jerusalem, where there was a temple of Jesus that had once existed. When Helena in her dream arrived at a hill in the temple, she saw several people digging right where Jesus had crucified. Some of these people later found three crosses which given to Helena. After obtaining the dream, Helena tried to prove the miracle of the three crosses she received against someone who was contracted by an illness. The first to the second cross did not succeed in curing the person's illness, only then when the three crosses were combined, the disease was successfully cured. Since then, began the glorification of the symbol of the cross (Ward, 1999). Although some people consider that the reason for the determination of the Christians symbol is cliched. And it's not categorized as a profane experience. That is because there is an assumption that the relation between symbols and their reference reasons cannot be logically proven. However, these conditions strengthen the theory of symbols, that often the existence of a logo cannot provide meaning directly.

This reality has led to the emergence of relevance between the meaning of symbols and things outside of human reality or logical contexts that universally believed (Segal \& Saliba, 1978). As for related symbols in a religion, it found in various references that the conception of symbols in Islam tends never to be explicitly discussed, both in the lexical and grammatical aspects. Arkoun said that Islam displays many forms of tokens through a semiotic approach in the style of language used in the Qur'an and alHadith. For example, in the use of the word Adam in every verse of the Qur'an. The word Adam does not only refer to the figure of the Prophet Adam as the first human created by Allah. But rather a symbolic expression for all humanity. Judging from the reality of this uniqueness, Arkoun tries to interpret the Qur'an in an integrative and synergetic way.

Namely, the combination of conventional and contemporary interpretations at the same time (Untung, 2010). Although primordially, there are still defects in the concept of semiotic analysis of the Qur'an by using Arkoun's theory. The location of the disability stems from Arkoun's principle of the Qur'an as a collection of texts with many errors and not perfection miracle. But in the perspective of semiotic, the scope of symbolic meaning raised by Arkoun through the existence of signs, symbols and myths can be used as a new solution point in understanding the nominal position in Islam. To show the existence of certain conditions, the Qur'an often packages its visualization using symbols. For example, in the display of the form of heaven, God often describes various types of pleasure. The existence of abundant food with a relaxed and calm atmosphere, as contained in Surah al-Baqarah, verse 25. In that verse, God sporadically said that a heaven is a place that cannot imagine and represented by pleasure in whatever form ever felt by humans during his lifetime on earth (al-Burhan, 2017). Symbols of visualization of heaven as a whole gave birth to a new meaning that happiness is a pleasure that could not be imagined by humans before.

Symbolic awareness in the Islamic religion has also made the times of the existence of 'ulama mutaqaddimin colored with syncretism. Evidenced by the emergence of various kinds of literary works, architecture, etc. that symbolically explain how the conception of Islam as a sacred religion. As a 
precedent, Islam recognizes the existence of dialectical symbols in realizing faith. If the logo interpreted by every word that is issued, then Islam through its textual sources, namely the Qur'an and as-Sunnah, becomes the most potent symbolic treasure and penetrates civilization. There were many architectural symbols associated with Islam, such as the shape of the moon, stars, etc. (Reat, 1975). Besides, there is also the dome symbol which architecturally interpreted as the vast scope of the universe created by Allah SWT by the scholars (Faghfoori et al., 2014).

Besides the meaning of dome architecture, there are also meanings from historical aspects. The dome defined as a work of art originating from Western and Eastern Roman culture before Islam conquered it. Where at that time, Roman fame in terms of aesthetic art influenced the style of architecture. And it is used in other orthodox Christian countries, such as Romania and Bulgaria. Relics of Roman building forms not considered substantive works that require Muslims to release them while in power. Until now, the dome, which has existed since ancient Greece, has undergone many modifications following the times. So, it can be concluded that the originality of the dome symbol not purely derived from Islam (Krautheimer \& Ćurčić, 1992). Many of the symbols claimed by Muslims originate from Islam, but if traced from the historical side of its existence, it has a different track record with these claims. It shows how biased the claims of authority over religious symbols. Turner views religious symbols, both in the form of attributes and rituals, as symbolic realism that may conflict with religious practices in other groups. It is due to differences in the supporting social groups on each symbol interpreted (Turner, 1988). Susanna Mancini, a professor of public comparative law at the Faculty of Law at the University of Bologna in Italy even researches about the tendency of symbol manipulation and secularity.

\section{Conclusion}

It must recognize that modern society, especially Muslims today, in identifying new phenomena, is not a constant binary opposition between truth and error. For example, in polemic religious symbols. The center of civilization has shifted peripherals into centers as well as centralistic obsessions with various causes. Therefore, an in-depth and wise search needed before concluding the position of a problem in the Islamic paradigm. In this context, religious symbols are not new in Islamic civilization. Its existence existed even before Islam came to earth. The intersection between civilizations and other national cultures is supported by the human desire to fulfil innate desires as a servant. This condition has implications for the birth of several forms of Islamic material symbols which have been agreed upon by the public at large. Diaspora religious or non-religious symbols that enter the order of human life urge a quick response as an expression of protection or guidance among Muslims. But in the process of responding to these symbols, the basic principles of Islam that firmly held, namely: (1) Religious symbols, such as semiotic and semantic theory, are something that is born purely from sacred texts and from human thought which broadly agreed; (2) The use of religious symbols must pay attention to the limitation criteria of tasyabbuh (Faghfoori et al., 2014); (3). However, the use of logos does not represent any object or concept; the impact of their application must still be considered based on the idea of sadd adz-dzariah (Krautheimer \& Ćurčić, 1992); (4) There is a moral-ethical element in the use of religious symbols, where social relations between Muslims will be more easily intertwined and possible to be a means of sharing Islam to humanity; and (5) The use of religious symbols does not allow cults to lead to the abyss of shirk. Often the existence of certain symbols used by Muslims is made a distinctive identity. This specificity leads to claims of meanings that lead to the presence of symbols in the community. Whereas if it traced to historical aspects as well as ideological and philosophical aspects, certain symbols could instead lead to other religions that experience Islamophobias tendencies. So can conclude that not all logos provide specific defining authority for Muslims.

\section{References}

Al-Burhan, M. Z. 2017, “Surga dalam Literatur Al-Quran.” Handbook Metodologi Studi Islam, ed. Batubara, C. 2018. Jakarta: Prenada Media.

Berger, P., and Kellner, H. 1964. "Marriage and the Construction of Reality." Diogenes 12(46): 1-24. doi: 10.1177/039219216401204601. 
Cooke, B., and Macy, G. 2005. "Christian Symbol and Ritual: An Introduction, Christian Symbol and Ritual: An Introduction.” New York: Oxford University Press. doi: 10.1093/0195154118.001.0001.

Croft, W. 1990. “Typology and Universals Second Edition.” Available at: http:/ /www.cambridge.org (Accessed: June 2, 2020). Crystal, D. 2008. A Dictionary of Linguistics and Phonetics. (Accessed: June 2, 2020).

Faghfoori, R., Ghehi, H. B. and Soltani, G. 2014. "Theosophical Principles of Light and Colour in the Architecture and Decorations of Soltaniyeh Dome.” International Journal of Arts 4(1): 8-16. doi: 10.5923/j.arts.20140401.02.

Hornby, A. S., Wakefield, H., and Gatenby, E.V. 1963. “The Advanced Learner's Dictionary of Current English.”. New York: Oxford Univ. Press.

Keene, M. 2006. “Seri Access Guides Agama-Agama Dunia.” Yogyakarta: Kanisius.

Krautheimer, R., and Ćurčić, S. 1992. "Early Christian And Byzantine Architecture.” London: Yale University Press.

Kriyantono, R., and Sos, S. 2015. "Public Relations, Issue \& Crisis Management: Pendekatan Critical

Lings, M. 1968. "The Qoranic Symbolism of Water, Studies in Comparative Religion." Available at: www.studiesincomparativereligion.com (Accessed: June 2, 2020).

Mirzazadeh, T. 2014. "Discrimination in the Name of Secularism: A Ban on Religious Symbols in Quebec." Global Business \& Development Law Journal 28(2): 412-434.

Pass, C. L., Bryan Lowes., and Leslie Davies. 2012. "Collins Dictionary of Economics.” Londong: Collins.

Peirce, C. 1960. "Collected Papers of Charles Sanders Peirce". Cambridge: Harvard University Press.

Reat, N. R. 1975. "The Tree Symbol in Islam, Comparative Religion.” Available at: www.studiesincomparativereligion.com (Accessed: June 2, 2020).

Saussure, F. 1959. "Course in General Linguistics." New York: The Philosophical Library.

Segal, R. A., and Saliba, J. A. 1978. "Homo Religious' in Mircea Eliade: An Anthropological Evaluation." Journal for the Scientific Study of Religion 17(1): 75. doi: 10.2307/1385436.

Simbol - Wikipedia, ensiklopedia bebas (no date). (Accessed: May 7, 2020).

Turner, B. S. 1988. "Individualism, Capitalism and the Dominant Culture: A Note on the Debate," The Australian and New Zealand Journal of Sociology 24(1): 47-64. doi: 10.1177/144078338802400103.

Untung, M. S. 2010. “Pembacaan Al-Qur'an Menurut Mohammed Arkoun.” Religia 13(1): 23-40.

Veeger, K.J 1985. "Realitas Sosial: Refleksi Filsafat Sosial Atas Hubungan Individu-Masyarakat Dalam Cakrawala Sejarah Sosiologi." Jakarta: Gramedia.

Ward, H. 1999. "History of the Cross: The Pagan Origin, and Idolatrous Adoption and Worship, of the Image." (Accessed: June 2, 2020). 